\title{
MAKING MARVELS: THAUMATOPOIIA AND THAUMATOURGIA
}

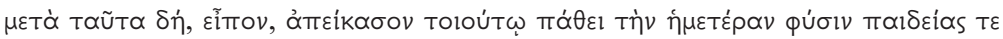

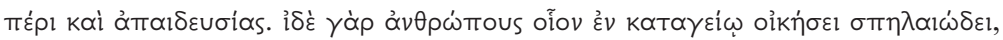

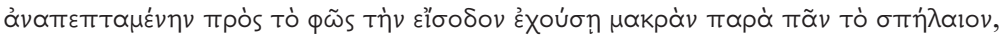

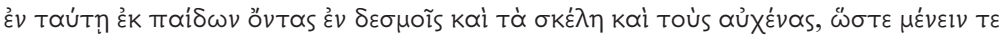

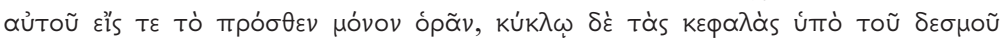

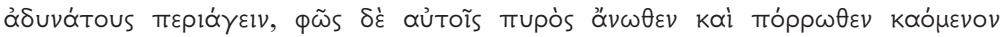

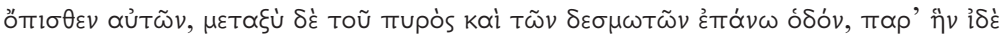

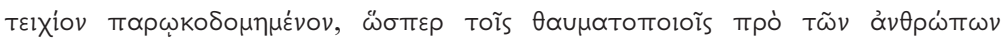

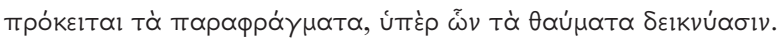

Plato, Republic 5 I4a-b

'After these things', I said, 'compare our nature, with respect to education and the lack of it, to such an experience as this one. See, as it were, men in a cave-like subterranean dwelling, with a long entrance facing towards the light along the entire length of the cave. The men have been in this cave from childhood, bound by their legs and their necks, so that they remain in the same place and see only what is before them, unable to turn their heads around in a circle because of the bonds. The light of a burning fire is above them and a long way off behind them, and in between the fire and the bound men there is a path going upwards, beside which see a little built-up wall, just like the screen which hides the marvel-makers

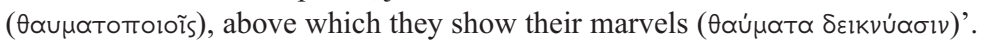

Plato's Cave Allegory, found at the very beginning of the seventh book of the Republic, is possibly the most famous single passage of text in Western philosophy. Plato's wider attitude towards wonder in this passage plays a role in this image which has often been underestimated. Thauma occupies a complex and multifaceted position in Plato's philosophical thought. On the one hand, he often portrays the effects of falling prey to the marvellous displays of sophists, poets, rhapsodes, actors and politicians as inherently negative, particularly for the young. But on the other hand, thauma also simultaneously seems to be an unparalleled catalyst to philosophical inquiry, as the young mathematician (and in many ways Socratic doppelgänger) Theaetetus demonstrates in 
the dialogue named after him. ${ }^{\mathrm{I}}$ This attitude hints that the presence of marvels in Plato's Cave Allegory is not an idle throw-away detail. In fact, the thaumata mentioned in the final sentence of this passage provide an interpretative key to the image as a whole.

My purpose in this chapter is twofold. I want to examine the introduction and use of the concepts of 'marvel-making' (thaumatopoiia) and 'wonder-working' (thaumatourgia) in Plato and elsewhere as a means of assessing the way attitudes towards wonder have shifted between Herodotus' Histories and the early fourth century BCE. In the process, I take Plato's Cave as a case study, and suggest a reading of the image through the lens of thauma which offers new perspectives on some of the passage's familiar problems. In particular, I want to approach one of the most commented-upon interpretative difficulties in this section of the Republic, namely our inability to map each element of the Cave image onto each outlined section of the preceding and interconnected image of the Divided Line in a precise one-to-one fashion, from a different angle. ${ }^{2}$ Rather than pointing to some sort of flawed philosophical planning on Plato's part, the fact that these images do not map precisely onto one another actually turns out to be essential to the argument Socrates is making in Republic 6 and 7. If we take the cues about how to read this image given to us by Socrates, we discover that the Cave is itself held up as a marvel of sorts, and that distorted mapping, strange perspectives and changing views are at the very heart of the effect of the marvel-maker's art and its effects.

But before returning to the Cave, it is necessary to explore the cultural context of 'marvel-making' much more broadly. The questions I want to raise have been surprisingly neglected in modern scholarship. ${ }^{3}$ What exactly is a thaumatopoios, and what

I See Chapter 2, Section 2, on the parallels between Socrates and Theaetetus as philosophical thaumata.

2 Cf. the comprehensive recent discussions of this issue in e.g. Annas (I98I) $252 \mathrm{ff}$., Karasmanis (I988) I47-7 I, Brunschwig (2003) I45-77 and Schofield (2007) 2 I 6-3I.

3 Kroll (I935) I278-82 remains the most comprehensive overview of thaumatopoiia. Milanezi (2004) I9I-3 provides the best brief discussion of the role of the real-life thaumatopoios while discussing various other types of minor paratheatrical entertainers (see also the very useful tables listing the appearances of terms for entertainers which appear in Athenaeus and on inscriptions on pp. 204-6). Cf. also the brief discussions concerning thaumatopoiia in Dickie (200Ia) 60I-2 and (200 Ib) 72-3. 
does his or her art - thaumatopoiia - consist of? Why do we start to find these two terms in the extant literature towards the end of the fifth and the beginning of the fourth centuries BCE? These questions will be at the heart of my discussion of marvel-making below. I will first try and establish what kind of actions fall under the umbrella terms thaumatopoiia (marvelmaking) and thaumatourgia (wonder-working), another synonymous compound word which begins to appear in this period; I will then return to the Cave Allegory to show just how complex and philosophically loaded the use of the marvellous has become in Plato's hands in this passage.

\section{I The Meaning of Marvel-Making: Theatrical Thaumatopoiia}

Compound words denoting artificial man-made marvel-making begin suddenly to appear in extant literature in the first half of the fourth century BCE, in Demosthenes, Isocrates and Plato. It is clear from looking at late Classical and Hellenistic uses of the term, as well as uses in later texts which refer back to marvelmaking in this period, that a variety of actions fall under the umbrella terms thaumatopoiia and thaumatourgia. The madeness inherent in both terms, and the fact the term is itself made by being compounded together, is important: artificiality is at the heart of the marvel-maker's art. Unlike the divine, natural and cultural marvels of the past, the thaumata described here are somehow worked by ordinary human hands, as opposed to appearing spontaneously in the landscape, or being somehow linked to the power of divine craftsmanship, or to artists with creative powers approaching those of the gods.

The word thaumatopoiia appears much more frequently than thaumatourgia. Perhaps the defining feature of a thaumatopoios is the fact that he or she specialises in performances in front of a captive audience, particularly in venues such as the theatre or symposium. The actual content of these performances could vary greatly. Variety (poikilia) is of course intimately connected to the aesthetic impact of thaumata, so it is no surprise that the versatility of the marvel-maker becomes one of the prime causes of the 176 


\section{I Theatrical Thaumatopoiia}

thaumatic impact of their performances. ${ }^{4}$ Mime actors, dancers and musicians are strongly linked to the art of the thaumatopoios: this reinforces the sense that the ability to perform spectacles of varying types is a key aspect of the role. ${ }^{5}$ Athenaeus provides us with perhaps the most interesting evidence concerning all of these aspects of the thaumatopoios' art. $^{6}$ In a prolonged discussion (Deipnosophistae I9e) of well-known performers of the past, the apparently famous thaumatopoios Xenophon is mentioned, along with his pupil Cratisthenes of Phlius, who astonished the crowds with baffling tricks, such as making fire spontaneously flare up. These two thaumatopoioi are mentioned immediately after two other famous figures who made their name in the theatre: Potheinus the puppeteer (neurospastes), who performed in the same theatre as Euripides, and Eurycleides, who was honoured with a statue in the theatre next to that of Aeschylus.

Many other sources situate the thaumatopoios within a theatrical or paratheatrical context. Particularly intriguing is the mention of thaumatopoioi alongside other theatrical artists in numerous choregic inscriptions from Delos in the third and second centuries BCE, which seems to have had a particularly flourishing marvelmongering scene. ${ }^{7}$ On multiple inscriptions, thaumatopoioi are listed alongside figures such as tragic poets and actors, comic poets and actors, and aulos and cithara players, including several

${ }^{4}$ On the variable nature of the activities which the term thaumatopoiia denotes from the fifth century BCE onwards, see Milanezi (2004) I92.

5 For the association between thaumatopoioi and mimoi, see Milanezi (2004) I92-3; cf. the brief discussion of the relation between Imperial stage-pantomimes and thaumatopoioi at Lada-Richards (2007) 3I.

6 Stephanis (1988) lists literary and epigraphic evidence of twenty-five potential thaumatopoioi in antiquity (see numbers 262, 320, 408, 4I 9, 766, 984, I03I, I092, I225, I304, I 45I, I496, I785, I 890, I894, I9I4, 2002, 2257, 2285, 2508, 2520, 2258, 2748, 2976, 2989). Of these, nine are mentioned in Athenaeus, the rest in inscriptions.

7 It is interesting that the epigraphic evidence for thaumatopoio $i$ at festivals clusters around Delos in particular, although it is difficult to know what to make of this in terms of specific Delian performance contexts. Given the lack of epigraphic evidence for the inclusion of thaumatopoioi in festivals alongside other theatrical performers in other parts of the Hellenistic world, it is hard to agree with Milanezi (2004) 200-I that thaumatopoioi are firmly attached to groups of technitai of Dionysus; Lightfoot's (2002) 2 I2 assessment that mimes and conjurors in the Hellenistic world were 'no less part of the festivals, if on their fringes', seeing as these figures 'are not shown as members of guilds in the Hellenistic period', is surely closer to the mark. Cf. also Slater's (2004) I55 view that one of the key differences between the Artists of Dionysus and thaumatopoioi is that the former are regulated whereas the latter are not. 
examples relating to one particular thaumatopoios, Kleopatra or Kleupatra (IG XI, 2 I IO, dated 268 BCE; IG XI, 2 II 2 , dated c. 264 BCE; IG XI, 2 II3, dated 263 BCE). Other named thaumatopoioi are mentioned on single occasions (cf. e.g. $I G \mathrm{XI}, 2$ I I 5, dated 259 BCE; $I G$ XI, 2 I 20, dated $236 \mathrm{BCE}$; $G$ XI, 2 I 29 , dated I 92 BCE; $I G$ XI, 2 I 33 , dated I 69 BCE). ${ }^{8}$ The use of the actual theatre as the scene of thaumatopoiia is hinted at in later sources as well, such as an anecdote found in Plutarch (Vit. Lyc. I9.2):

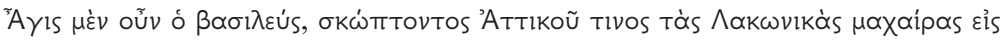

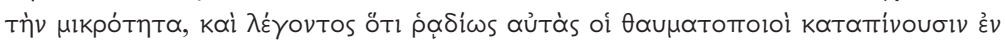

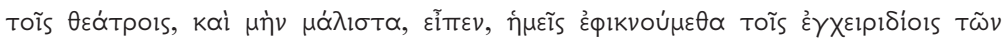

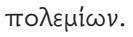

When a certain Attic man mocked Laconian swords for their shortness, and said that the marvel-makers in the theatres swallow them easily, King Agis replied: 'And yet we certainly reach the enemy with these daggers'.

But the question of how exactly the displays of thaumatopoioi related to other kinds of performance within the theatre itself is impossible to answer from the evidence that remains. Did these spectacles compete with the large-scale theatrical performances of tragedy and comedy for the audience's attention, or operate entirely separately from these productions?

There is some evidence that displays of thaumatopoiia often functioned as more strictly paratheatrical endeavours, competing with the more established and prestigious forms of performance. The sense that displays of thaumata competed with other types of theatrical performance is perhaps strongest in one intriguing passage from Plato's Laws. Unsurprisingly, given his attitude towards even the more conventionally educative types of performance, the ability of theatrical thaumata to distract and dazzle the minds of spectators is a particular concern of Plato here. In a passage which focuses on the differing appeal of various pleasures to various people depending upon their age, the Athenian Stranger argues that in a contest of different types of performances, where the 'the contest was over

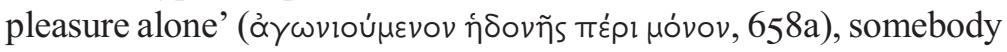

\footnotetext{
${ }^{8}$ See Robert (1929) 427-38 on this group of inscriptions dealing with the theatre at Delos. I 78
} 


\section{I Theatrical Thaumatopoiia}

would naturally put on a display of thaumata in an attempt to delight an audience $(658 b-c)$ :

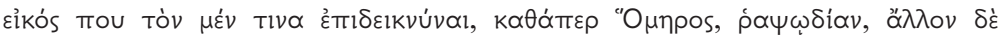

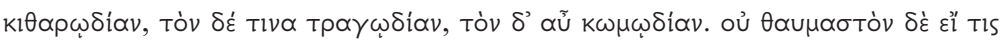

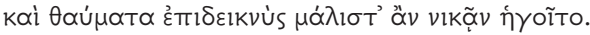

I suppose it is likely that one man would put on a recitation of epic poetry, just as Homer did, and another would stage a citharodic performance, someone else would put on a tragedy, and someone else a comedy. And it would be no marvel if someone thought they might win by putting on a display of marvels.

The Athenian Stranger goes on to add that he can already predict the winner of this pleasure contest depending on the age of the judges in charge of making the final decision. Displays of thaumata are said to appeal more than any other sort of entertainment to young people, with the seemingly inevitable result that 'if the very smallest children are judges, they will judge in favour of the person putting on a display of thaumata' ( $\varepsilon \dot{l} \mu \dot{\varepsilon} v$ Toívuv Tà $\pi \alpha \dot{\alpha} v \cup$

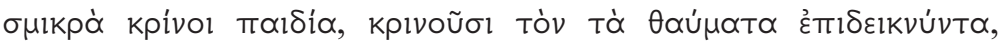
$658 \mathrm{c}) .{ }^{9}$ In contrast, the more solemn and weighty performances of tragedy will appeal to 'educated women and young men and the

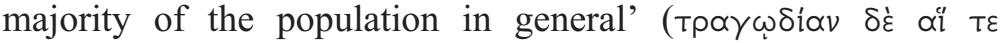

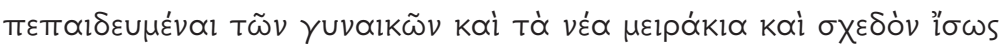
Tò $\pi \lambda \tilde{\eta} \theta$ os $\pi \alpha \dot{\alpha} v \tau \omega \nu, 658 \mathrm{~d}$ ), while 'old men would take pleasure in listening to a fine rhapsodic performance of the Iliad and Odyssey or a recitation from Hesiod and will declare that to be the definite

9 Theophrastus also makes vague mention of such displays of thaumata twice in his Characters: the man who possesses 'shamelessness' (ámóvola) is said to be the sort who goes around 'collecting money from each person watching thaumata' ( $\dot{\varepsilon} v \theta \alpha u \dot{\mu} \mu \alpha \sigma \mathrm{\delta} \dot{\varepsilon}$

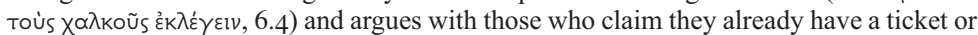

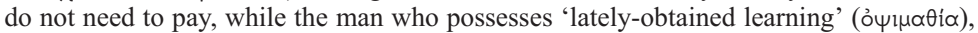
which seems in the Characters to mean a liking for things appropriate for boys but inappropriate for anyone in an older age group, enjoys 'sitting through three or four

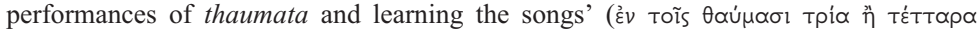

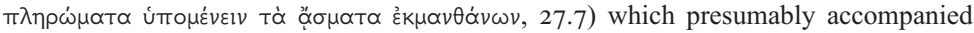
the shows. The first mention implies that displays of thaumata were put on with the aim of collecting money (cf. the Syracusan dancing master's purveyance of sympotic thaumatopoiia in Xenophon's Symposium in Section 2 below), while the second suggests that such displays sometimes involved a musical element and were deemed appropriate for, or thought to appeal appropriately to, younger audience members rather than older male citizens. I will discuss what type of display Plato is thinking of when he refers to thaumata here when I return to the thaumata of the Cave in Republic 7 in Section 4 below. 


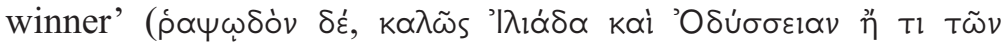

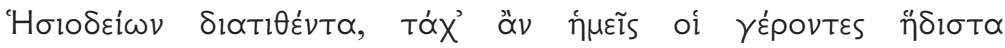

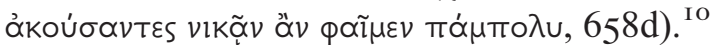

Public displays of thaumata to large-scale audiences are therefore portrayed in the Laws as a particularly dangerous prospect, due to the fact that they provide pleasure without much educative content to match. It is difficult to assess how much truth there is in Plato's worries here, since it is only when we turn to the Roman world in the second century BCE that we encounter an obvious comparandum. In the first and second prologues of Terence's Hecyra the failures of the comedy's first attempted performances are explicitly blamed on a 'disaster which prevented the play from being seen or understood' (calamitas $\mid$ ut neque spectari neque cognosci potuerit, 2-3): a disaster which led to the theatrical production at hand being ignored when the 'amazed audience were distracted by their enthusiasm for a tightrope-walker' ( lus studio stupidus in funambulo | animum occuparat, 4-5). The second prologue hints at yet another theatrical failure: this time the crowd are distracted again by the sudden emergence of a rumour concerning the potential appearance of boxers and 'the expectation of a tight-rope walker' (funambuli ... exspectatio, 34). ${ }^{\text {I I }}$ The distracting acrobatic feats of the tightrope-walker are precisely the sort of spectacles associated with thaumatopoioi. Although it is of course impossible to say whether a similar incident could have occurred in the context of Greek theatrical festivals, it is nonetheless not difficult to imagine that the spectacles of thaumatopoioi could prove equally distracting if offered at the same time as theatrical performances with weightier themes, narrative complexity, and potentially edifying content - as Plato has indeed hinted while mentioning displays of thaumata in the Laws.

Io See Folch (20I3) 342-5 and (20I5) I3 I-6 on the relationship between pleasure and the diverse genres and forms included in this hypothetical competition in the context of the wider argument about the necessary nature of the hypothetical society of Magnesia in the Laws.

${ }^{11}$ For good discussions of the play's supposed initial failure and its relation to the potential appearance of rival distracting spectacles in the vicinity of its performance, see e.g. Gilula (I98I) 29-37, Sandbach (I982) I34-5, Parker (I996) 592-60I, Lada-Richards (2004) 55-82 and Goldberg (2013) I 5-I 8, 86-96. 


\subsection{Sympotic Thaumatopoiia}

\subsection{Sympotic Thaumatopoiia: Wonder-Working in Xenophon's Symposium}

Theatrical or paratheatrical settings are not the only areas in which the thaumatopoios frequently plies his or her trade: the symposium is an equally common venue for marvellous performances. The sense that these smaller-scale displays of thaumata also aim at distracting and capturing the minds of their spectators with amazement is also very clear. There is one extant text which explores the effect of wondrous performative marvels in a sympotic context in great depth: Xenophon's Symposium. The dialogue is set in 422 BCE, at the house of the famously rich Athenian Callias. Throughout Xenophon's Socratic dialogue, an antithesis arises between spectacular displays of feats held up as 'marvels' and philosophical questions about 'marvellous' natural phenomena. This suggests that there are now important differences to be drawn between wonder provoked by the gods or the natural world, and wonder provoked by the dazzling - and often deceptive - actions of our fellow humans.

Performative marvels involving bodily display are of particular interest in Xenophon's dialogue, becoming a prime topic of conversation over the course of the drinking party. ${ }^{\text {I2 }}$ The serious philosophical conversation at Callias' symposium is provoked in no small part by the acrobatic feats of a beautiful dancing girl provided by a Syracusan dancing master, who is on hand to provide entertainment at the host's house from the very beginning of the symposium proper (2.I):

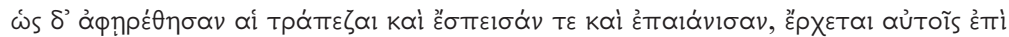

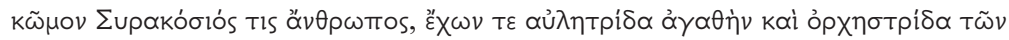

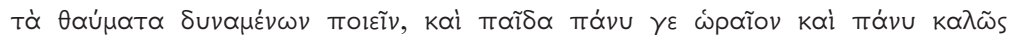

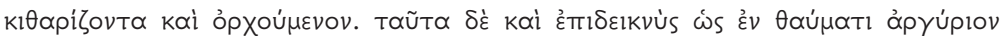
$\varepsilon \dot{\lambda} \lambda \dot{\alpha} \mu \beta \propto \nu \varepsilon v$.

When the tables had been taken away and they had poured a libation and sung a paean, a Syracusan man on a komos arrived. He was accompanied by a girl, an excellent aulos player and dancer, one of those able to make marvels, and a boy

12 Wohl (2004) 337-63 and Gilula (2002) 207-I3 discuss the wider connections between the pronounced interest in bodily display and the philosophical concerns of the dialogue. 
who was very good-looking and very talented at playing the cithara and dancing. The Syracusan made money by exhibiting them as something to marvel at. ${ }^{13}$

The girl's art is here described as that of 'making marvels', and she is clearly some kind of female thaumatopoios. ${ }^{\text {I4 }}$ With the Syracusan dancing master's ability to make wondrous amounts of money from the marvellous displays he directs, Xenophon here links thaumatic display and pecuniary gain in a manner reminiscent of Plato's frequent cynical wordplay on this theme. The Hippias Major is a good example. At the beginning of the dialogue, Socrates mentions to Hippias that his fellow sophist Prodicus is well known for obtaining a wondrous amount of money ( epideixis and association with the young. Hippias goes on to confirm that contemporary sophists are marvelled at not only for their performances but also for the absurdly large amounts that they are able to make. He tells Socrates that even though he is already aware of how much money Prodicus is said to make, and therefore would not be surprised at the fact Hippias makes money

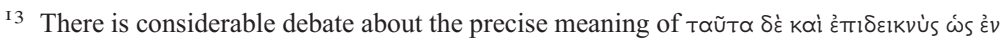

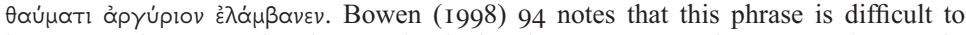
interpret and suggests that the meaning is that the Syracusan makes money 'in remarkable sums' rather than that the performers are exhibited 'as something to marvel at' because the former interpretation also hints at Callias' wealth (and presumably his ability to pay the Syracusan wondrous sums) by extension. Huss (I997) 43-4 and (I999) I2 I makes a strong case for emendation of the singular $\theta \alpha u$ ú $\mathrm{Tl}$ to the plural,

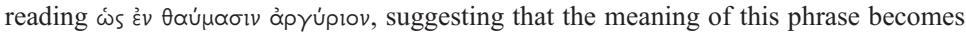
something along the lines of 'he showed them as in performances at a fair'. The phrase is still, however, deliberately ambiguous in meaning and it is clear that the Syracusan means to suggest here both that he displays his performers as something for others to marvel at, and that he makes a marvellous amount of money by doing so.

${ }^{14}$ As Huss (I999) I2 I points out. See Schäfer (I997) 79-8I on what these scenes in Xenophon's Symposium suggest about the emergence of professional sympotic entertainers in the second half of the fifth century BCE. The connection between thaumatopoiia and sympotic eroticism which Xenophon draws out here is an enduring one if Matro's parodic epic poem Attic Dinner Party (late fourth century BCE), quoted by Athenaeus, is anything to go by. As soon as dinner has ended in that poem the necessary preparations for the symposium are made: hands are washed, garlands are distributed, wine is mixed and the flat cake arrives. This is swiftly followed by the introduction of

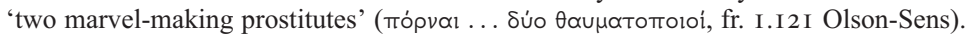
See Olson and Sens (I999) I43 on the use of thaumatopoioi here as a humorous suggestion that these prostitutes are not simple dancing girls, but actually able to perform wondrous acts in bed. Cf. also Athenaeus' report (Deipnosophistae I29d) of the wedding feast of Caranus the Macedonian, which allegedly involved naked female thaumatopoioi tumbling amongst swords and breathing fire. 


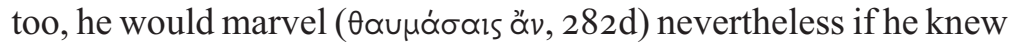
just how great that sum of money was. Hippias even goes so far as to claim that when he gives the money he has made on the road to his father back home in Elis, 'both his father and the other citizens

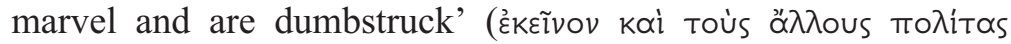

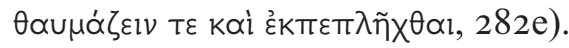

The bitter irony here directed at the abilities of sophists to make ludicrous amounts of money is increased by the fact that the same terms are used elsewhere in Plato for the effect of the actual displays of sophistic or rhapsodic performances on their audiences. The astonishment which grips those who view Hippias' sophistic displays - and the piles of money he makes from them is remarkably similar to that which rhapsodes are said to have on their audiences in another of Plato's aporetic dialogues, Ion. ${ }^{15}$ This is most obvious when we reach the rhapsode Ion's own discussion of the audience's response to his art, after Socrates has first suggested to him that 'whenever you recite epic well astonishment

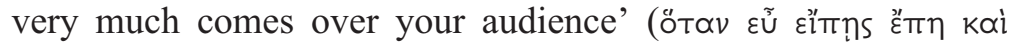

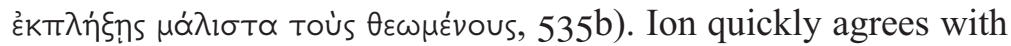
Socrates and goes on to describe the experience from his point of view $(535 \mathrm{~d}-\mathrm{e})$ :

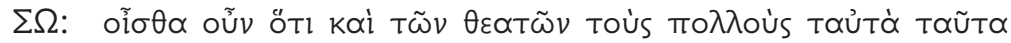

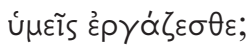

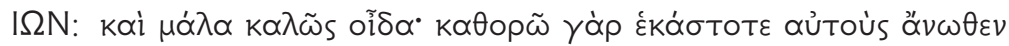

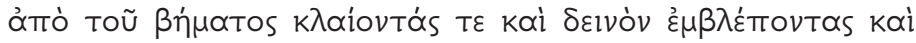

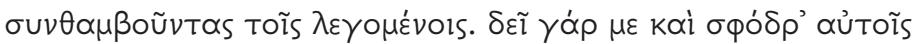

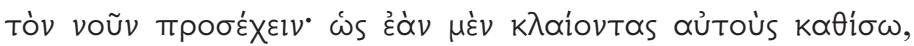

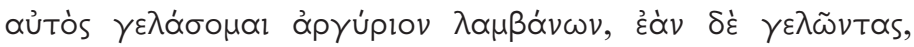

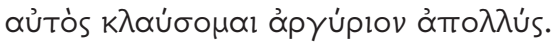

SOCRATES: And so do you think that you produce the same effects on most of the spectators as well?

I5 See González (20I3) 290 on the 'direct line' between rhapsodic hypokrisis and sophistic epideixis. See Ford (I992) 54-5 on the significance of Plato's Ion 535b-e as a conceptualisation of the vivid and astonishing experience which the audience experiences in the presence of the rhapsode during a performance of epic poetry. 
Ion: Yes, I know this full well: for each time from up on the platform I look down at them weeping and glaring formidably and totally astonished at my words. For it is very much necessary for me to pay attention to them, since if I make them cry, I myself will laugh at the money I make, but if I make them laugh, I myself will cry at my lost income.

The effect of viewing a sophistic epideixis, watching one of Ion's vivid and emotionally manipulative rhapsodic re-enactments of epic poetry, or glimpsing a huge pile of money is precisely the same: they induce a stultifying sense of astonishment.

Xenophon too is playing on this same idea in the Symposium as the troupe of entertainers arrives; already we have hints of the negative associations between marvel-making and moneymaking which go on to affect our view of the displays of thaumatopoiia proper later in the dialogue. ${ }^{16}$ The main discussion of thaumatopoiia and its effects comes at 7.2-4. This passage first describes how in the middle of the symposium 'a potter's wheel was brought in for the dancing girl, on which she was about to work her

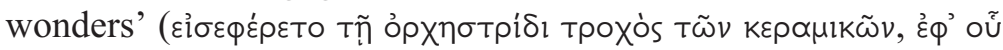

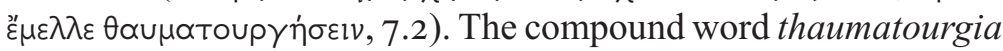
is being used in the same way as thaumatopoiia here; the two are clearly synonyms denoting the types of spectacular display which are deliberately worked by men or women in an effort to astonish an audience. ${ }^{17}$ We have evidence for the type of thaumatic acrobatic feat described here on fourth-century BCE South Italian vases: a red-figure Paestan skyphos in the Ashmolean Museum (Oxford I945.43) depicting a naked young woman performing a handstand upon a potter's wheel which is being rotated by a Phlyax actor, is the example which perhaps comes closest to

I6 The emphasis on the Sicilian provenance of the dancing master in the Symposium also perhaps hints at the spectacles which will go on to be served up at the symposium later in the dialogue. There is certainly an awareness of Sicilian performance traditions in Plato's dialogues: see e.g. Monoson (2012) I56-72 on the importance of Sicilian theatrical traditions in Plato's philosophical and political thought in the Republic. More generally, see Morgan (2OI2) 48-54 on the rise of Syracuse as a flourishing literary and theatrical centre over the course of the fifth century BCE.

${ }^{17}$ See Milanezi (2004) I 87 on the use of thaumatourgia and thaumatopoiia as synonyms which denote the same sorts of action in the fourth century BCE; cf. Huss (I999) 348 on the equivalence of thaumatourgia and thaumatopoiia in this passage. 
Xenophon's description of the dancing girl's thaumatourgia in the Symposium. ${ }^{18}$ Far from being rare marvels, these sorts of manoeuvres seem to have become performative commonplaces, as Socrates' subsequent response to this display of the dancing girl suggests $(7 \cdot 3-4)$ :

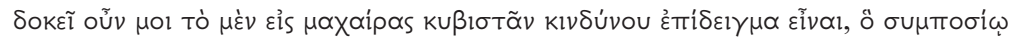

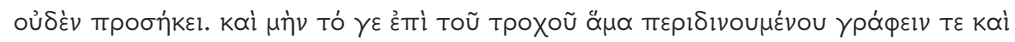

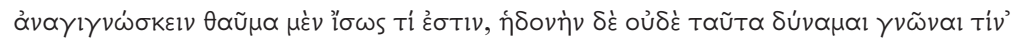

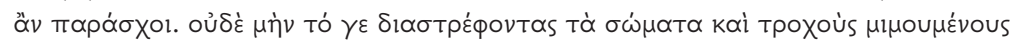

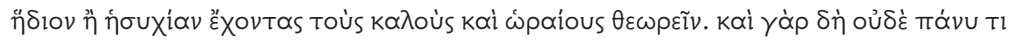

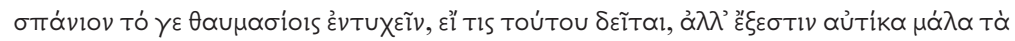

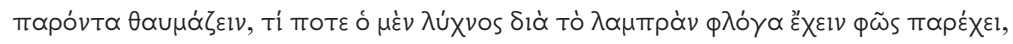

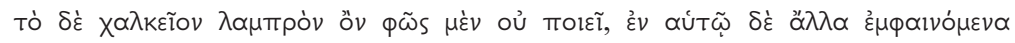

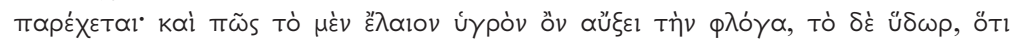

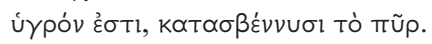

It seems to me that to somersault into swords is a dangerous showpiece, something not fit for a symposium. Perhaps writing and reading on a potter's wheel while it whirls around is something of a marvel, but I can't think what pleasure it might provide. Nor is it more pleasurable to observe young and good-looking people twisting their bodies out of shape and imitating the wheels of potters than it is to watch them at rest. Of course, it's not at all a rare thing to encounter marvels, if somebody feels a need, rather it's possible to marvel just this very minute at the things right in front of you. For example, why does the lamp provide light with its bright flame, but the bright bronze lamp bowl does not provide light,

${ }_{18}$ This skyphos is attributed to Asteas (or his workshop) and dated to the third quarter of the fourth century BCE. For plates and discussion see PPSupp p. 34, no. I I6, pl. V b; $P h V^{2}$ p. 58, no. 96; and $R V P$ p. 69, no. 33, pls. 24 f-g. Vickers (I999) 74 notes the particular similarities between the scene depicted on this vase and the description of the wonder-working dancing girl's performance in Xenophon's Symposium: cf. also Dearden (1995) 8I-6. See Marshall (2000) I3-25 for a discussion of this vase and what it might tell us about women and the theatre; cf. Hughes (2008) I I-I 2 on vases with depictions of acrobats on potters' wheels more generally. Among several other vases which portray a female acrobat either performing on a potter's wheel, or apparently gearing up to do so, the closest to the scene described in Xenophon include: (I) Sydney, Nicholson Museum 95.I 6 (c. 325-3Io BCE, attributed to an artist related to the Woman-Eros Painter), which depicts a female acrobat doing a handstand on a potter's wheel along with two large birds (see CVA Australia I 64-5, pls. 84-5); (2) British Museum F 232 (c. 340-330 BCE, attributed to the Foundling Painter), which shows a scantily clad female acrobat performing a handstand next to a potter's wheel and tympana (see CVA British Museum 2 (Group IV Ea, Red-Figured Vases of Campania and Paestum) p. 6 and pl. 8.4 and LCS I 3/I I 2 (p. 375) with LCS II pl. I43.3); (3) Naples, Museo Archeologico Nazionale 509 (SA 405), which depicts a female acrobat on a potter's wheel accompanied by an auletris (see CVA Naples III, p. I6, pl. 70.4). On the iconography of vases such as these, and for results of recent experiments to recreate the postures of the female thaumatopoioi upon them, see Pulitani et al. (20I7) 35-56. 
instead giving out onto itself only the reflections of other things? And how does olive oil increase a flame, though it is wet, while water, which is also wet, extinguishes fire?

Socrates is clearly not impressed by the dancing girl's thaumatourgia. His insistence here that it is not at all a rare event to encounter marvels makes clear that the sorts of questions provoked by not understanding the causes behind natural, everyday sights and processes in the world around us are what we should really be impressed and excited by, rather than the spectacles artificially developed by human performers. ${ }^{\text {I }}$ The interplay between the near and the far which we have already seen to be increasingly connected to the marvellous towards the end of the fifth century BCE is obviously on Xenophon's mind here as well: once again, 'real' marvels are now considered to be found more often surprisingly close to home among familiar objects, rather than far away, or involving rare objects or actions. Moreover, as mentioned earlier, the acrobatic postures which the dancing girl performs in this dialogue are frequently encountered in later visual art, and from Socrates' weary mention of such feats here, it is no great stretch to posit that for Xenophon's contemporary readers, sword-dancing and whirling about on wheels while reading and writing were already familiar kinds of sympotic display. ${ }^{20}$

Socrates' view here is clear: it is the customary material of natural science - and of philosophy - that we should really be wondering about, not a girl whirling about on a potter's wheel.

I9 In this respect Socrates' words about near and distant objects and topics which provoke thauma here in Xenophon's Symposium are the closest antecedent of Aristotle's similar way of framing the issue at Metaph. 982b I2-2 I and Part. an. 644b-65a (for a more detailed discussion of these passages, see Chapter 3, Section 4).

${ }^{20}$ On the evident familiarity of these types of sympotic display, see Jones (I99I) I90-I. Familiarity is certainly suggested at Pl. Euthyd. 294e, where Socrates challenges the sophist Dionysodorus and asks him if he even knows how 'to leap among swords and be

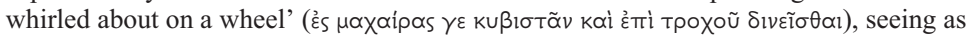
he claims to have knowledge of everything. It is no coincidence that Socrates implies that Dionysodorus is like a sympotic thaumatopoios here since his sophistic arguments, along with those of his brother Euthydemus, are strongly associated with thauma and

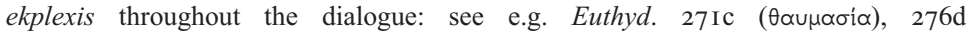

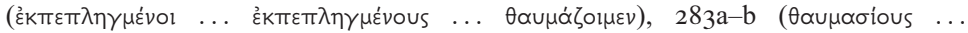

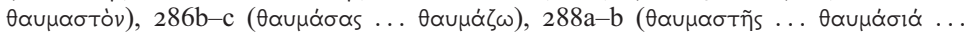

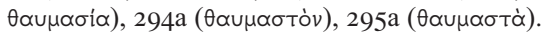


Once again, we see that there is a division being made here between the type of wonder which spurs someone on to further inquiry and involves a mostly cognitive aspect, and that which is purely affective and as a result often leads to the sort of stunned cognitive stasis commonly associated with the term ekplexis. In Xenophon's Symposium, the fact that natural marvels provide the material for the former sort of wonder, while man-made marvels are associated with the latter, is laid out in perhaps its starkest form in Socrates' lengthy meditation upon the true nature of rare and familiar thaumata - the irony of course being that educated men such as himself would supposedly never find the sorts of acrobatic marvels displayed in Callias' house worthy of any astonishment. The risk of this type of stultifying astonishment, however, remains for the young, uneducated or foolish, and it is precisely for this reason that thaumatopoiia becomes such a worry for Plato and other contemporary thinkers, as the next section will demonstrate in more detail.

\subsection{Thaumatopoiia and Perspective in Plato's Republic and Sophist}

There is another aspect of Socrates' speech in Xenophon's Symposium which relates to connected concerns surrounding thaumatopoiia: the fact that the performance he refers to when he complains about young people twisting their bodies round and imitating the wheels of potters is a mimetic one. ${ }^{21}$ Some of the problems associated with mimesis in Plato's work also come to be associated with marvel-making. One important aspect of Plato's treatment of thaumatopoiia is its relation to the discussion of

${ }^{21}$ Gilhuly (2009) I29 picks up on the thaumatic effect of the mimetic nature of the wonderworking girl's actions upon the potter's wheel: 'in this feat, mimesis closes in on itself. The girl enacts the process by which she is objectified, becoming the vessel that depicts her presence at a symposium. She is the material of her own representation - the clay and the pots and the knives and the image and the word. The real and representational realms collapse on each other in meaningless mimesis, and there is nothing for the spectators to do but marvel.' The importance of ideas about mimesis in this dialogue more generally has also been picked up on by Wohl (2004) 357-8 and Baragwanath (20I2) 64I, who note that the behaviour of the Syracusan's performers in the Symposium seems to shift from performative mimesis to supposedly 'real' actions in the mime depicting the relationship between Dionysus and Ariadne with which the dialogue ends. 
artistic mimesis in book Io of the Republic, and in the later dialogue Sophist. In these dialogues thaumatopoiia and mimesis both relate to problems which arise as a result of changes in distance, measurement, proportion and perspective. As we saw in earlier chapters, the relationship between the near and the far and thauma in Greek thought in the fifth century is a very complex one. As we might expect, thauma comes into Plato's discussions of the near and the far as well, in both a literal and a metaphorical sense.

In Republic I0, Socrates argues that mimesis is not the second stage distant from truth (i.e. the second stage away from the

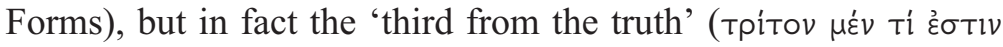
åmò $\tau \tilde{\eta} s ~ \alpha ُ \lambda \eta \theta \varepsilon i \alpha s, 602 \mathrm{c})$. He then states that the power of mimesis affects the same part of us as visual illusions. He explains this point by noting that the 'dimensions of the same object do not seem to be the same when viewed both from close up and from far

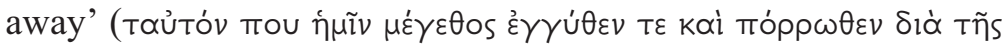

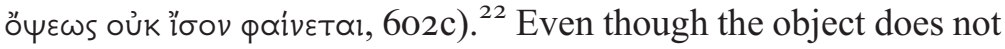
actually change its magnitude in reality, it seems to be a different size depending on where the viewer is stood. Other errors of perception are similar to this kind of effect $(602 c-d)$ :

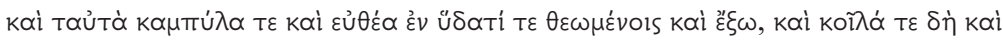

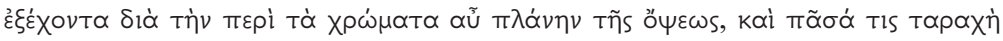

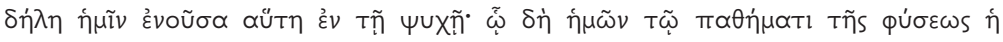

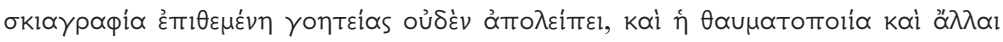

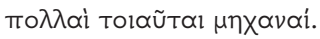

And the same things look bent within water and straight outside of it, and both concave and convex, again because of visual error concerning colours, and every single confusion like this is clearly inherent in the human soul. Three-dimensional painting (skiagraphia), which attacks this weakness in our nature, is nothing short of bewitchment, as is marvel-making (thaumatopoiia) and all other such artifices.

Skiagraphia and thaumatopoiia are here equated with the effect that mimesis itself supposedly has on the spectator. In Plato, both of these terms are interconnected in ways that suggest that a deceptive, spurious appearance of truth is the aim of mimesis.

${ }^{22}$ Cf. Ion's sentiments at Eur. Ion 585-6: see Chapter 5, Section 4. 


\subsection{Thaumatopoiia and Perspective in Republic and Sophist}

Skiagraphia, often translated as 'shadow painting', seems to be the use of darker and lighter shades together in such a way as to give figures the impression of three-dimensionality. ${ }^{23}$ Distance is key to skiagraphia: the lengths of lines and/or the colours used only look correct from a distance, and fail to stand up to detailed scrutiny when viewed up close. As Eva Keuls puts it, in the realm of painting, skiagraphia represents 'the epitome of illusionism ... the device which most intensively exploited the subjectivity and fallibility of human eyesight'. ${ }^{24}$ The way in which skiagraphia exploits this power of illusion seems to be by making things look more real rather than less: objects on a flat plane somehow take on the appearance of three-dimensional objects, even though they are just flat depictions of real-life objects. Moreover, the sort of play with distance and magnitude in which the purveyors of skiagraphia and thaumatopoiia indulge is a key aspect of the sort of ekplektic wonder that these thaumatic objects provoke: this fits with the connection of thauma to the visual in general, and to extremes of magnitude (things which are either amazingly big or amazingly small) and distance (things which should be far away appearing closer to you than you imagined, or vice versa) which we find elsewhere long before Plato begins to manipulate these ideas.

But there is an important development in the way in which these ideas are wielded for philosophical purposes here. Rather than referring in a strictly literal manner to real-life material objects, Plato's discussion of distance and thauma also takes on an important metaphorical aspect. This is made clearer in a similar discussion in the later dialogue the Sophist. As one of the steps in the long conversation with Theaetetus which aims to define what, exactly, a sophist is, the Eleatic Stranger first, in a subsection of the argument beginning at $234 \mathrm{~b}-\mathrm{c}$, pinpoints the ability to deceive people through the use of visual or verbal mimesis as a key aspect of the sophist's character:

${ }^{23}$ For a detailed discussion of skiagraphia see Bruno (I977) 37; cf. Rouveret (I989) 24-6, 50-9 and Burnyeat (I999) 223-4.

24 See Keuls (I978) 80 . 


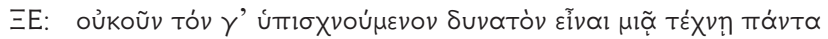

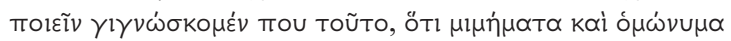

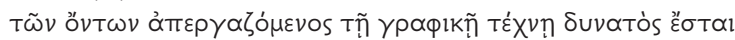

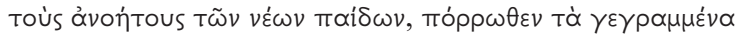

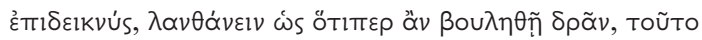

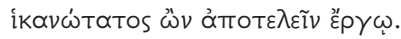

$\Theta E: \pi \tilde{s} \gamma$ à oü;

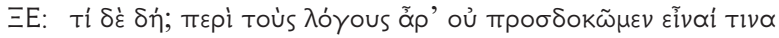

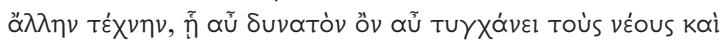

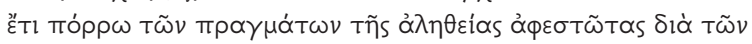

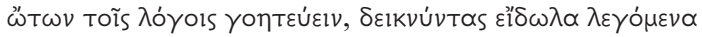

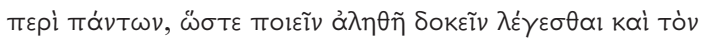

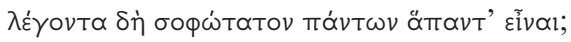

Eleatic Stranger: And so we recognise this I suppose about the person who professes to be able to do everything with a single art: that by producing imitations which have the same names as real things through the art of painting, and by displaying his pictures at a distance, he is able to deceive the unintelligent ones among young children into thinking that he is supremely able to carry out any deed he wishes to do in reality.

Theaetetus: Yes, indeed.

Eleatic Stranger: Well then? Surely we should expect that there is another art concerning words, with which it is again possible to bewitch the young through their ears while they are still standing far-off from the reality of things, displaying images of all things to them, so as to make it seem that true things are said, and that the man saying them is indeed the wisest of all men about all things?

In this case it is specifically mindless young children who are at risk of believing that one man can make or do all things by virtue of a single art. These children are therefore the ones most at risk of being deceived by this type of man through his use of illusionistic 


\subsection{Thaumatopoiia and Perspective in Republic and Sophist}

painting or similar mimetic arts. This deceptive use of visual art is shown to have an analogous counterpart in the deceptive use of verbal art; the sophist is further defined as one who can trick young people with words (234c). In this discussion, it is clear that a viewer's literal distance from a mimetic artistic object is parallel to a sort of metaphorical epistemic distance of the mind from truth itself. ${ }^{25}$

Given that the ability to dazzle someone with deceptive mimetic performances is a key aspect of marvel-making, it comes as no surprise when the Eleatic Stranger concludes that one of the key elements of the definition of the sophist is that he is a thaumatopoios as well. ${ }^{26}$ At $235 \mathrm{a}-\mathrm{b}$, the idea of the sophist as a type of marvel-maker is first introduced:

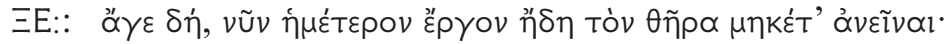

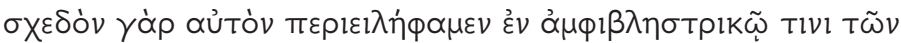

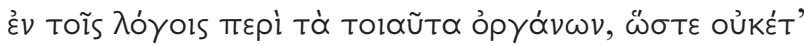

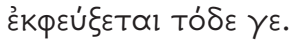

ӨE:: тò Trõ̃ov;

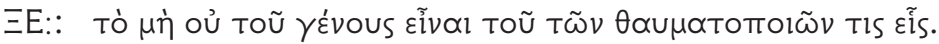

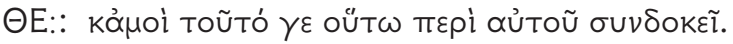

Eleatic Stranger: Come on then, it's our task not to let the beast escape. For we nearly have him surrounded with one of those net-like instruments which words provide for such things, so he will not escape from the next point.

Theaetetus: What point is that?

Eleatic Stranger: That he certainly belongs to the class of marvel-makers.

Thenetetus: This seems to me too to be true about that man.

The sophist's art ultimately keeps the young far away from the truth in the same way as illusionistic effects in painting such as skiagraphia necessitate a literal distance from the artwork in order

25 See Nightingale (2002) 228. Cf. also Socrates' very similar argument in relation to painting and mimesis at Resp. 598a-d.

26 See Casadesús Bordoy (20I2) 26 and Bernabé (20I2) 53-5 on the importance of thauma in this definition of the sophist. 
to create a convincing image. The sophist's ability to enthral the young and keep them far away from the truth turns him into a sort of thaumatopoios, a marvel-maker who constructs artificial thaumatic arguments which maintain the appearance of reality. Plato's discussion of nearness and distance in relation to thaumatopoiia and thaumata is therefore a distinctive element of his wider epistemological concerns.

\subsection{Socratic Marvel-Making: Thaumatopoiia in the Cave}

To return to the Cave. In this passage Plato again meditates upon the many associations surrounding displays of thaumata and mimesis, the relationship between the natural and the artificial, and familiar and unfamiliar wonders. Plato activates all these meanings in the Cave to warn against the potentially misleading and stultifying marvels of others - all the while having Socrates himself present a captivating image that does much to arrest and grab hold of the reader. If we focus on the use of wonder in this passage, Plato's wider message becomes clear: certain types of philosophical wonder can lead to educative and cognitive advancement, but in the hands of the wrong people thauma, though often pleasurable, can only lead to a state of cognitive stasis. This is a particular danger for the young person who is as yet not sufficiently educated to withstand the potential lure of deceptive thaumatic spectacles. This distinction is in fact made clear within the Cave Allegory itself. As we saw above, for Plato the concept of thaumatopoiia involves a series of interlinking issues involving perception, potential deception and mimesis. How then does this relate to the display of shadowy thaumata found in the Cave?

It is worth thinking further about how, exactly, the thaumata on display might appear to those watching the spectacle. From the description of the fire burning behind the prisoners from a long way off, and the low wall in front of them above which shadows are projected, it seems that we are dealing here with some form of shadow puppet theatre. ${ }^{27}$ The choice of this particular variety of thaumatic spectacle is especially apt, as the issues involving

${ }^{27}$ See Gocer (I999) I I9-29 on Plato's use of the idea of shadow puppetry in the Cave Allegory. 
perception and mimesis which Plato often associates with thauma and thaumatopoiia are massively accentuated by the way in which the composition of this spectacle is described. The prisoners in the Cave are not only forced to observe shadowy imitations of the objects being held up behind them rather than the objects themselves, they cannot even observe the true proportions of the shadows cast in front of them. This is the result of many factors: their distance from the wall of the Cave will affect their ability to measure the size of each shadow accurately, the use of a flickering fire as a light source presumably results in distorted and moving shadows, and the shadows may differ radically in size from the objects which cast them anyway depending on the relation between those objects and the fire itself. ${ }^{28}$ The distortions always associated with thaumatopoiia are thus in play in the Cave Allegory as well.

The spectators in the Cave are thus not only deceived by the fact that they think that the shadows are real objects, but also by the fact that they cannot even grasp the real dimensions of these shadows. Nor can they understand the causes of the movements of these objects: instead of understanding that the shadows can only imitate the movements of animate beings, they think that the shadows themselves are alive, especially since the voices of the thaumatopoioi-like men rebound off the wall of the Cave and make the shadows seem to speak. The objects casting shadows are made to look like statues of men or other living things, but they are not living creatures. Instead they have all been constructed out of materials like wood and stone (5I4c-5I5a):

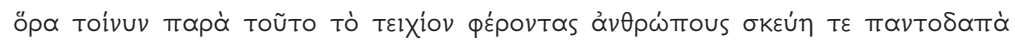

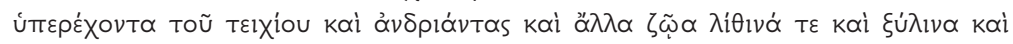

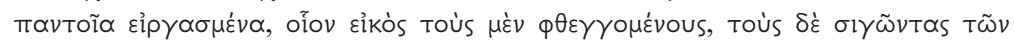
$\pi \alpha \rho \alpha \varphi \varepsilon \rho \dot{v} \tau \omega \nu$.

Schofield (2007) 226 notes that the dazzling and flickering nature of the fire would make it hard for the released prisoner to look at the objects casting shadows, but we can apply this principle further and note that even the shadows, especially their proportions, would be difficult to see clearly due to the moving nature of the light source. Cf. Harte (2007) 208 on potential distortions caused by the relation between the objects casting shadows and their light source. We might also note that the irregularity of the cave wall would presumably cause the shadows to appear even more distorted to their viewers. 
And now picture this: along this wall there are men bearing all sorts of props which project above the wall, both images of men and other living creatures made out of wood and stone and all sorts of materials. As you would expect, some of the men carrying the props along utter sounds, and some are silent.

The fact that these objects have been constructed out of other materials is very important: these are not thaumata which are found in the natural world, the kinds of everyday marvels which provoke the types of questions which lead to philosophical thinking. Instead they are deceptive images which aim to deceive and dazzle the onlooker with thauma in the same way that artworks which look 'as if they are alive' or 'as if they are about to speak' provoke a similar sense of wonder in their viewers. ${ }^{29}$ The effect of the shadows is comparable - except that the chained viewer in the Cave does not realise that they are caused by artificial and manmade objects.

If the shadows are the ultimate in deceptive mimetic spectacles, then the thaumatopoioi-like men must represent the type of people who create these kinds of mimetic sights. In general, the recent voluminous scholarship on this passage has subscribed to one of two views: either the men in control of the thaumata which enthral the prisoners are politicians and legislators, or they represent men who are prominent in the cultural sphere such as poets, artists, playwrights and painters. ${ }^{30}$ There is no need to decide between these groups: both are covered by the designation of the figures controlling the objects in the Cave as being like thaumatopoioi, since politicians and demagogues by necessity harness the powers of thauma in their speeches to play to the crowd just as poets and artists do. In a similar fashion, thaumatopoiia is

29 See Chapter 2, sections I, 3 and 4 on wonder as the customary response to statues or other types of artworks which are rendered so realistically that they seem to be on the verge of moving or speaking as though truly alive.

30 Wilberding (2004) I I7-39 provides a comprehensive overview of the many recent suggestions regarding the identity of the people compared to thaumatopoioi in the Cave Allegory. Wilberding himself argues that all of these orthodox views are wrong and that the puppeteers are not orators, demagogues, politicians or poets. Instead, he suggests that the prisoners are meant to represent these groups, and that the shadows are the demos. Given the performative bent of thaumatopoiia, however, it seems clear that the more conventional readings of this passage cohere more easily with Plato's use of the language of thauma in Republic 7. 
being used metaphorically here in disparaging reference to the potentially seductive and deceptive art of any public figure who attempts to influence the thought and direction of the rest of society. ${ }^{3 \mathrm{I}}$

The power of such representations over the spectator is made very clear by Socrates' vision of the Cave's prisoners. As we have seen in earlier chapters, intensely or excessively wondrous displays often run the risk of provoking stunned astonishment in their audiences, a dumbstruck response which often also leads to a (usually temporary) sort of somatic paralysis. It is not by accident then that the absolutely static state of the chained prisoners echoes the position of those who elsewhere in Plato's dialogues are described as subject to the pleasurable but damaging charms of ekplektic wonder, since Plato is referring precisely to the same types of figures orators, poets, rhapsodes, demagogues - whom he elsewhere accuses of misleading the general public, and the young in particular, with ekplektic and wondrous displays. The fact that the prisoners are fettered only emphasises the paralysing and stultifying effect of the thaumata on show and demonstrates how extraordinarily difficult the task of ever escaping or overcoming the marvellous power of these superficially pleasurable spectacles really is.

Given the emphasis on visual illusion and the power of arresting sights (whether they be actual visual objects or verbal descriptions of visual objects) at which the introduction of thaumatopoiia in the Cave Allegory hints, is it necessary for us as readers of Plato to pause and question the power of Socrates' own verbal painting? I believe that we must do so, not least because of the way in which the necessity of actually seeing the image that Socrates is constructing is emphasised to his interlocutor Glaucon (and, by extension, to us). At the very beginning of the account, Glaucon is

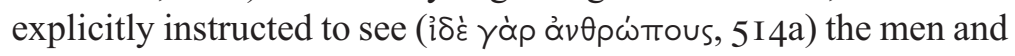
their surroundings which Socrates is about to describe, and this

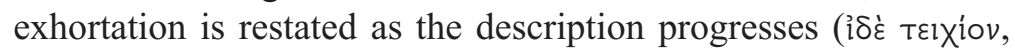
5 I 4 b). At the end of Socrates' initial illustration of the situation in the Cave, Glaucon responds by explicitly saying that he sees what

3I Thus McCoy (2008) I30 is correct in noting that: '[w] hat is crucial in the use of this term here [i.e. $\theta \alpha \cup \mu \alpha$ топогіоs] is that the speakers are performers'. 


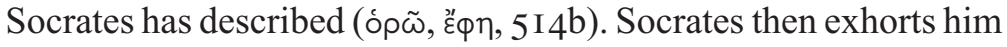
to see again (öpa, 5I4b), proceeding to recount how men carrying images of men and other living things cast shadows upon the wall of the Cave. Although Glaucon claims he can see what Socrates is describing, and we can also follow along and imagine what the Cave might look like, it is difficult to understand straightaway what this image is supposed to convey. Socrates has already told us at the very beginning of the Cave Allegory that what he is about to

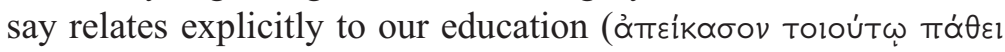

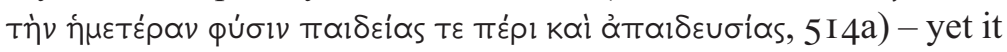
is difficult to understand immediately how the situation of the prisoners bound in the Cave could relate to this theme. Likewise, although we can visualise various elements of Socrates' description in our minds, the significance of the image being built up in front of us is not easy to grasp. Just as the prisoners in the Cave fail to understand the true significance and causes of the moving shadows on the wall, so too do we fail to grasp the true purpose of the image built up by Socrates and its relation to our education until we are guided through the image by someone who already understands its meaning.

This point is emphasised further by Glaucon's initial response at the end of Socrates' description: 'This image you speak of is strange', he said, 'and these are strange

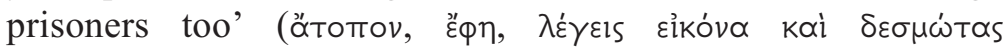
ótómous, 5I5a). In this case the spatial aspect of the word atopos - literally meaning 'out of place' - is also activated in Glaucon's comment, as he implies that both the space of the Cave and the people in it are 'out of place', spatially and conceptually distant from his own existence and consciousness. ${ }^{32}$ But Socrates reveals that these men are surprisingly much closer to Glaucon than he has realised: 'they are like us' (ónoíous ì $\mu \tilde{i} v, 5$ I5a), he bluntly replies. Socrates has thus managed to make the familiar strange and the strange familiar, to defamiliarise and then refamiliarise the supposed

32 See Nightingale (2004) 97 on the importance of atopia later on in the Cave Allegory when the philosopher himself will eventually go on to become atopos among his own people; this later reversal of the application of atopia echoes and transforms Glaucon's use here.

I96 
situation of those who are just like us. ${ }^{33}$ Wonder is a frequent response to this kind of defamiliarisation and refamiliarisation, and it is precisely that response which Socrates' image is attempting to provoke, both in Glaucon and in us. The Cave Allegory is itself offered up to us here as an object of thauma though one that potentially offers the possibility of cognitive advancement rather than stasis, as long as we are correctly guided through and eventually manage to move away from the alluring nature of images, whether they are visual or constructed verbally.

In this way, the potential danger of falling prey to wonderinducing images is a theme which is itself encoded within the Cave Allegory. By making a marvel of his own, Socrates by necessity distorts certain elements of his image, increasing the magnitude of some aspects and minimising the importance of others. This causes particular problems when we attempt to harmonise the image of the Cave with what we have previously been told about the Line. ${ }^{34}$ But the lack of precise harmonisation between these images in Republic 6 and 7 is itself no wonder: distortions and changing proportions are after all at the heart of thaumatopoiia. Any image which works to arrest our attention and make us marvel is bound to mislead us to some extent, as Plato frequently warns us. ${ }^{35}$ The difference in Socrates' use of thauma in this case is that it makes us think; it sets us off on the process towards the realisation that it is mathematical and dialectical reasoning which is necessary for us to approach an understanding of the Form of the Good. This is something we only come to

33 Cf. Nightingale (2004) 96 on Plato's 'rhetoric of estrangement' in this passage, which 'aims to uproot and displace us, portraying the familiar world as strange and the strange reality of the Forms as kindred to the human soul'.

34 Schofield (2007) 230 best sums up the resulting problems: 'The assumption that we are being told to bludgeon everything in the Cave to fit whatever parallels could be identified in Sun and Line has caused much of the interpretative damage.'

35 Even Socrates' own wonder-inducing words are not immune from thauma's potentially double-edged effects in Plato's dialogues: see e.g. Alcibiades' description of the often astounding effects of Socrates' speech, arguments and behaviour in the Symposium, where thauma and ekplexis make very frequent appearances in relation to the older man's words and actions (see Symp. 2 I 5b, 2 I 5d, 2 I6c, 2 I6d, 2 I 7a, 2 I 9c, 220a, 220b, $220 \mathrm{c}, 22 \mathrm{Ic})$; cf. the use of the famous stingray image in the Meno (80a-b), where the potentially stunned result of engaging in elenctic discussion with Socrates looks remarkably similar to the paralysing effects of ekplektic wonder. 
realise as the Cave Allegory draws on: as Myles Burnyeat notes, 'it is only in retrospect that we learn that the Cave has to do with mathematics as well as cultural values $(532 \mathrm{~b}-\mathrm{c}){ }^{\prime} .{ }^{36}$ From a distance, at first glance, we might think the image of the Cave is only about cultural values. But as Socrates brings us (and Glaucon) closer and closer to his true meaning, we realise close up that the main purpose of this image is to impress the necessity of mathematical and dialectical reasoning upon us. The Cave Allegory thus itself embodies the way in which wonder is one of the most dangerous weapons in the arsenal of those who are pre-eminent in the cultural and political spheres in contemporary Athens, the thaumatopoioi-like men who construct crowd-pleasing marvels for their own ends. But the other face of thauma is present in the Cave as well, and its potential as an initial protreptic towards further philosophical endeavour becomes clear: in the right (Socratic) hands, 'wondering' truly does turn out to be the 'begin-

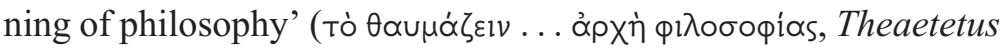
I55d).

${ }^{36}$ Burnyeat (I999) 243. 